\title{
QUEEN'S
UNIVERSITY
BELFAST
}

\section{Self-assembling diphenylalanine peptide nanotubes selectively eradicate bacterial biofilm infection}

Porter, S. L., Coulter, S. M., Pentlavalli, S., Thompson, T., \& Laverty, G. (2018). Self-assembling diphenylalanine peptide nanotubes selectively eradicate bacterial biofilm infection. Acta Biomaterialia, 77, 96-105.

https://doi.org/10.1016/j.actbio.2018.07.033

\section{Published in:}

Acta Biomaterialia

\section{Document Version:}

Peer reviewed version

Queen's University Belfast - Research Portal:

Link to publication record in Queen's University Belfast Research Portal

\section{Publisher rights}

(c) 2018 Elsevier.

This manuscript is distributed under a Creative Commons Attribution-NonCommercial-NoDerivs License

(https://creativecommons.org/licenses/by-nc-nd/4.0/), which permits distribution and reproduction for non-commercial purposes, provided the author and source are cited.

\section{General rights}

Copyright for the publications made accessible via the Queen's University Belfast Research Portal is retained by the author(s) and / or other copyright owners and it is a condition of accessing these publications that users recognise and abide by the legal requirements associated with these rights.

Take down policy

The Research Portal is Queen's institutional repository that provides access to Queen's research output. Every effort has been made to ensure that content in the Research Portal does not infringe any person's rights, or applicable UK laws. If you discover content in the Research Portal that you believe breaches copyright or violates any law, please contact openaccess@qub.ac.uk. 
Self-assembling diphenylalanine peptide nanotubes selectively eradicate bacterial biofilm infection

Simon L. Porter, Sophie M. Coulter, Sreekanth Pentlavalli, Thomas P. Thompson, Garry Laverty*

Biofunctional Nanomaterials Group, School of Pharmacy, Queen's University Belfast, Medical Biology Centre, 97 Lisburn Road, Belfast, N. Ireland, BT97BL.

\section{Corresponding author:}

Dr Garry Laverty,

School of Pharmacy

Medical Biology Centre

Queen's University Belfast

97 Lisburn Rd

Belfast

BT9 7BL

Tel: +44 (0) 2890972273

Email: garry.laverty@qub.ac.uk 
Abstract

Biofilms present a major problem to industry and healthcare worldwide. Composed of a population of surface-attached microbial cells surrounded by a protective extracellular polysaccharide matrix, they are responsible for increased tolerance to antibiotics, treatment failure and a resulting rise in antimicrobial resistance. Here we demonstrate that selfassembled peptide nanostructures composed of a diphenylalanine motif provide sufficient antibacterial activity to eradicate mature biofilm forms of bacteria widely implicated in hospital infections. Modification of terminal functional groups to amino $\left(-\mathrm{NH}_{2}\right)$, carboxylic acid $(-\mathrm{COOH})$ or both modalities, and switch to d-isomers, resulted in changes in antibacterial selectivity and mammalian cell toxicity profiles. Of the three peptide nanotubes structures studied $\left(\mathrm{NH}_{2}-\mathrm{FF}-\mathrm{COOH}, \mathrm{NH}_{2}\right.$-ff- $\mathrm{COOH}$ and $\left.\mathrm{NH}_{2}-\mathrm{FF}-\mathrm{NH}_{2}\right), \mathrm{NH}_{2}-\mathrm{FF}-\mathrm{COOH}$ demonstrated the most potent activity against both planktonic (liquid, free-floating) and biofilm forms of bacteria, possessing minimal mammalian cell toxicity. $\mathrm{NH}_{2}-\mathrm{FF}-\mathrm{COOH}$ resulted in greater than $3 \log _{10} \mathrm{CFU} / \mathrm{mL}$ viable biofilm reduction (>99.9\%) at $5 \mathrm{mg} / \mathrm{mL}$ and total biofilm kill at 10 $\mathrm{mg} / \mathrm{mL}$ against Staphylococcus aureus after 24 hours exposure. Scanning electron microscopy proved that antibiofilm activity was primarily due to the formation of ion channels and/or surfactant-like action, with $\mathrm{NH}_{2}-\mathrm{FF}-\mathrm{COOH}$ and $\mathrm{NH}_{2}$-ff- $\mathrm{COOH}$ capable of degrading the biofilm matrix and disrupting cell membranes, leading to cell death in Gram-positive bacterial isolates. Peptide-based nanotubes are an exciting platform for drug delivery and engineering applications. This is the first report of using peptide nanotubes to eradicate bacterial biofilms and provides evidence of a new platform that may alleviate their negative impact throughout society.

Keywords: Peptide; biofilm; infection; nanotube; drug delivery; biomaterial. 


\section{Introduction}

Surface-attached biofilm forms of bacteria are responsible for approximately $80 \%$ of all infections [1]. Biofilm bacteria are a sessile community characterised by cells that are embedded within an extracellular polymeric matrix and exhibit an altered phenotype with respect to growth rate and gene transcription compared to planktonic bacteria. Biofilms demonstrate increased resistance characteristics and are associated with treatment failure in chronic wounds and implant associated infections where standard in vitro susceptibility assays (e.g. minimum inhibitory and bactericidal concentrations) do not correlate to clinically effective concentrations [2]. They are responsible for high rates of morbidity and mortality within infectious diseases such as cystic fibrosis, dental, wound and medical device infections. A major difficulty encountered clinically is that biofilm forms commonly require 10 to 1000 times the concentration of antibiotic to achieve bactericidal action compared to more susceptible free-floating, liquid planktonic forms. Biofilms lead to a profile of increased tolerance to antibiotic therapy; survival of a bacterial population exposed to a subtherapeutic concentration of antibiotic and increased spread of antimicrobial resistant strains [3]. The gel-like extracellular polysaccharide biofilm matrix presents a physical barrier to: phagocytosis and the host's immune response; opsonization; the diffusion of antibacterials and physical/shear stress. Biofilms are primarily anionic in charge and have the ability to bind to and prevent the permeation of several cationic antibiotics including aminoglycosides [4]. Bacterial cells situated within the lower depths of the biofilm are therefore relatively protected from environmental and therapeutic stress. This enclosed environment allows the community of bacteria to share genes, including those that code for multidrug resistance, via plasmid exchange [5]. Resistance to antimicrobials is one of the most pressing issues impacting society resulting in at least 700,000 deaths worldwide per year [6]. The Centers for Disease Control and Prevention estimates that drug-resistant bacteria cause two million illnesses and approximately 23,000 deaths each year in the US alone. Recognising the severe threat to society, the US government released a $\$ 1.2$ billion five-year national action 
plan in 2015 aimed at combating antibiotic-resistant bacteria [7]. Therefore efforts have focused on alleviating the burden of biofilm-based infections using a variety of innovative approaches including the use of antimicrobial peptides [8], non-thermal plasma [9] and antibiotic-decorated nanoparticles [10]. During our study of peptide-based nanomaterials [11], we discovered that diphenylalanine (FF) peptide nanotubes were able to selectively eradicate mature 24 hour biofilms of bacteria implicated in a variety of infections. FF represents the minimal peptide motif for self-assembling nanostructures and also more significantly to this work, antibiofilm activity. Their mode of action is via disruption of the exopolymer biofilm matrix and targeting of bacterial cell membranes. They were particularly effective against biofilm forms of Gram-positive staphylococci widely implicated in endocarditis, intravascular catheter, wound and bone infections [12].

Peptide nanotubes have been studied as next generation materials for a variety of chemical, technological, engineering and drug delivery applications [13]. Similar to carbon nanotubes, they possess an advantageous high aspect ratio (length-to-diameter) which is important to mediate cellular interactions including cell internalization as observed by Gratton and colleagues [14]. The Mitragotri group has previously demonstrated that tubular nanoparticle structures provide improved transport and delivery of drugs throughout the body, adhering better to cells than spherical particles due to a larger surface area in contact with target cells [15]. This group also demonstrated that nanotubes possess an enhanced surface area allowing greater encapsulation efficacy of drug relative to alternative platforms, such as nanospheres, nanocubes and liposomes, meaning more drug reaches its intended site of action at a lower therapeutic dose combined with a reduced likelihood of drug induced systemic side effects [16]. Compared to carbon and metallic nanotubes, peptide variants possess the additional benefits of improved chemical versatility due to the range of amino acid functional groups, enhanced biocompatibility, tunable biodegradability and variable immunogenicity [17]. Interest in dipeptide nanotubes, for example the FF motif, is particularly high as the reduced amino acid chain length makes their synthesis and manufacturing 
upscale more cost-effective and amenable to widespread industrial applications [18]. Figure 1 (a-c) outlines the structure of the FF motifs studied, with (a) representing FF with a carboxylic acid terminus $\left(\mathrm{NH}_{2}-\mathrm{FF}-\mathrm{COOH}\right)$, (b) corresponding the d-enantiomeric isomer of (a) $\left(\mathrm{NH}_{2}-\mathrm{ff}-\mathrm{COOH}\right)$, and (c) FF possessing two amino terminals $\left(\mathrm{NH}_{2}-\mathrm{FF}-\mathrm{NH}_{2}\right)$. Each is synthesized using Fmoc-based protocols. FF motifs have the ability to spontaneously selfassemble into nanotubes in solution due to intermolecular $\pi-\pi$ interactions between neighboring phenyl groups, hydrophobic interactions and hydrogen bonding with surrounding solvent, leading to primarily $\beta$-sheet secondary structures as previously demonstrated (Figure 1d) [19].

a)<smiles>NC(=C=P)C(=O)OC(=O)C(Cc1ccccc1)NC(=O)C(N)Cc1ccccc1</smiles>

b)<smiles>NC(Cc1ccccc1)C(=O)NC(Cc1ccccc1)C(=O)O</smiles>

$\mathrm{NH}_{2}-\mathrm{ff}-\mathrm{COOH}$ c)<smiles>NC(=O)C(Cc1ccccc1)NC(=O)C(N)Cc1ccccc1</smiles>

$\mathrm{NH}_{2}-\mathrm{FF}-\mathrm{NH}_{2}$

d)

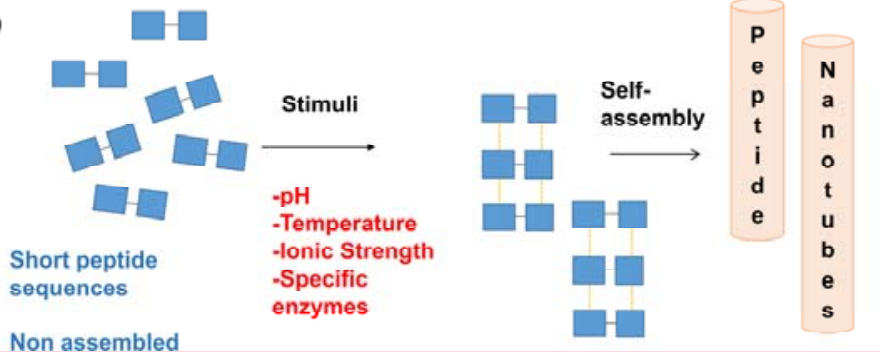

Figure 1. Structure of diphenylalanine peptides utilized in this study (a-c). (d) Peptide nanotubes are composed of amino acid building blocks. Each has the ability to selfassemble, via intermolecular interactions into nanotubes structures, in response to a variety of stimuli including: $\mathrm{pH}$, temperature, ionic strength, and the presence of specific enzymes. 
2. Materials and methods

2.1 Materials

Lyophilized $\mathrm{NH}_{2}-\mathrm{FF}-\mathrm{COOH}, \mathrm{NH}_{2}-\mathrm{ff}-\mathrm{COOH}$ and $\mathrm{NH}_{2}-\mathrm{FF}-\mathrm{NH}_{2}$ peptides were purchased from GL Biochem (Shanghai, China) as acetate salts at $\geq 95 \%$ purity. Staphylococcus aureus NCTC 10788, Staphylococcus epidermidis ATCC 12228, Pseudomonas aeruginosa ATCC 15692 and Escherichia coli ATCC 15597 were purchased from LGC Standards (Teddington, UK). UltraPure ${ }^{\mathrm{TM}} \mathrm{DNase} / \mathrm{RNase}$-free water and LIVE/DEAD® viability/cytotoxicity fluorescent assay were purchased from Thermo Fisher Scientific (Northumberland, UK). Minimum biofilm eradication concentration (MBEC) assay ${ }^{\mathrm{TM}}$ plates were purchased from Innovotech (Edmonton, Canada). 96-well microtiter plates (Nunc), N-Phenyl-1naphthylamine (NPN), polymyxin B, glutaraldehyde and cacodylic acid were purchased from Sigma-Aldrich (Dorset, UK). CellTiter 96® AQueous One Solution Cell Proliferation Assay was obtained from Promega (Southampton, UK). ${ }^{1} \mathrm{H}-\mathrm{NMR}$ spectra were obtained using a Bruker Ultrashield Plus $400 \mathrm{MHz}$ (Bruker, Coventry, UK). Mass spectra were provided by electrospray mass spectroscopy (Thermo Finnigan LCQ Deca ion trap, Thermo Fisher Scientific, Waltham, Massachusetts, USA). Peptide purity was elucidated by reverse-phaseHPLC (Agilent 1260 series, Agilent Technologies Ltd, Cork, Ireland), using a Gemini $\mathrm{C}_{18}$ column $(250 \mathrm{~mm}-4.6 \mathrm{~mm})$ with a flow rate of $1.5 \mathrm{~mL} / \mathrm{min}$ and gradient of $2-60 \%$ acetonitrile (30 minutes) in $0.05 \%$ TFA-water. All peptides were found to have purity greater than $95 \%$. Scanning electron microscope (SEM) images were taken on a JEOL JSM 6500 F SEM (JEOL, Freising, Germany). Fluorescence analysis was performed on a Tecan Sunrise plate reader (Tecan UK Ltd, Reading, UK). LIVE/DEAD® staining and optical NCTC 929 cell images were taken on fluorescence microscope (EVOS FL microscope, Thermo Fisher Scientific, Waltham, Massachusetts, USA) and processed using ImageJ software version 1.8 (National Institutes of Health, Bethesda, Maryland, USA). The physiochemical properties of peptides were estimated using Chemicalize software (ChemAxon, Cambridge,

Massachusetts, USA). Branson 3510 sonic bath was obtained from Branson Ultrasonics and 
was utilized to remove biofilms from MBEC pegs for viable counting (Danbury, Connecticut, USA).

\subsection{Methods}

\subsection{1. ${ }^{1} \mathrm{H}$ NMR analysis}

Peptide identities were confirmed using ${ }^{1} \mathrm{H}$ NMR analysis in deuterated DMSO ( $\left.\mathrm{d}_{6}-\mathrm{DMSO}\right)$. NMR experiments were carried out on a Bruker Ultrashield Plus $400 \mathrm{MHz}$ (Bruker, Coventry, UK). Peptides were identified using a 64-scan proton NMR analysis. To prepare samples 15 mg of peptide was dissolved in $\sim 550$ microliters of deuterated DMSO immediately before testing. Spectra were processed and identities confirmed using ACD labs academic NMR processor (Figures S1-S3).

\subsubsection{Peptide nanotube formulation}

The stepwise formulation of nanotubes is outlined in Table 1. $\mathrm{NH}_{2}-\mathrm{FF}-\mathrm{COOH}, \mathrm{NH}_{2}-\mathrm{ff}-\mathrm{COOH}$ or $\mathrm{NH}_{2}-\mathrm{FF}-\mathrm{NH}_{2}$ was dissolved in sterile UltraPure ${ }^{\mathrm{TM}}$ DNase/RNase-free distilled water at room temperature. To allow peptides to quickly reach their monomeric fully dissolved state, the peptide suspensions are heated to $65^{\circ} \mathrm{C}$ for 30 minutes and then allowed to selfassemble at room temperature over a period of 24 hours [20,21]. To achieve the working peptide nanotube concentration range, a stock solution is formed at $10 \mathrm{mg} / \mathrm{ml}$. This stock solution is vortexed and examined visually to confirm complete dissolution of the peptide powder. This is followed by immediate serial dilution to test concentrations with UltraPure ${ }^{\mathrm{TM}}$ DNase/RNase-free distilled water before assembly occurs at room temperature over 24 hours. The $\mathrm{pH}$ of peptide nanotube suspensions was titrated to $\mathrm{pH} 7 \pm 0.2$ with approximately $20 \mu \mathrm{L}$ of $1 \mathrm{M} \mathrm{NaOH}$ solution to ensure $\mathrm{pH}$ was constant. 


\subsubsection{Scanning electron microscope (SEM) nanotube imaging}

Peptides nanotubes were formulated as outlined above. $80 \mu \mathrm{L}$ of each peptide nanotube suspension was pipetted onto the SEM sample mount and allowed to evaporate overnight in a solvent fume hood. A JEOL JSM 6500 F SEM (JEOL, Freising, Germany) was used for SEM imaging at $3 \mathrm{kV}$, with each sample pre-coated with an $8 \mathrm{~nm}$ layer of gold.

\subsubsection{Tissue culture analysis}

Cell cytotoxicity was assessed using a murine fibroblast subcutaneous connective tissue NCTC clone 929 (ATCC® CCL-1) cell line. Cells were cultured in Minimum Essential Medium (MEM) containing phenol red with Earle's Salts and L-glutamine, supplemented with $10 \%$ horse serum (Invitrogen, Paisley, U.K.). Cells were grown at $37^{\circ} \mathrm{C}$ and $5 \% \mathrm{CO}_{2}$ and subcultured at 80-90\% confluency. Subculturing involved removal of spent media, washing with sterile phosphate buffer saline (PBS) and detachment of cell monolayers with $0.05 \%$ trypsin/0.53 mM disodium ethylenediaminetetraacetate dihydrate solution (Invitrogen, Paisley, UK). Cells were cultured until at least third passage and inoculated at $1 \times 10^{4}$ cells per well in 96-well microtiter plate and incubated for 24 hours. The media was then removed and the cells exposed to $100 \mu \mathrm{L}$ of a range of peptide nanotube samples for 6 hours. Control wells included media only (100\% viability, negative control) and $70 \%$ ethanol treated cells (100\% kill, positive control). A LIVE/DEAD® Viability/Cytotoxicity fluorescent assay (Thermo Fisher Scientific, Waltham, Massachusetts, USA) was used alongside fluorescence microscopy (EVOS FL microscope). Following 6 hour incubation with each peptide nanotube concentration, NCTC 929 cells were incubated for 20 minutes with a mixture of $4 \mathrm{mM}$ ethidium homodimer-1 and $2 \mathrm{mM}$ calcein $\mathrm{AM}$ in $\mathrm{pH}$ 7.4 PBS. Viable cells stained green due to the conversion of calcein AM to calcein, whilst nonviable cells stained red due to ethidium homodimer-1. Three randomly chosen areas were selected for analysis, with 200 cells quantified for the presence of viable (green) and non-viable (red) cells. Cell viability was also 
examined using the CellTiter 96® AQueous One Solution Cell Proliferation Assay, a colorimetric method allowing assessment of cell viability due to the presence of the tetrazolium compound 3-(4,5-dimethyl-2-yl)-5-(3-carboxymethoxyphenyl)-2-(4-sulfophenyl)$2 \mathrm{H}$-tetrazolium (MTS). Following 6 hours incubation with varying concentrations $(10-0.625$ $\mathrm{mg} / \mathrm{mL}$ ) of each peptide nanotube suspension, media containing nanotubes was removed and $90 \mu \mathrm{L}$ of fresh media added to each of the wells. $10 \mu \mathrm{L}$ of the reagent solution was added to each well of the microtitre plate and incubated for 1 hour. In the presence of viable cells, MTS tetrazolium compound is bioreduced to a colored formazan product. Plates are read spectrophotometrically at an absorbance of $490 \mathrm{~nm}$ using a using a Tecan Sunrise plate reader (Tecan UK Ltd, Reading, UK). Tissue culture assays were performed as triplicate with six replicates at each concentration. Percentage cell viability was calculated using the following equation where background refers to $10 \%$ MTS reagent in media:

$\%$ Cell viability $=$

Absorbance 490nm peptide treatment - Absorbance 490nm background Absorbance 490nm negative control - Absorbance 490nm background $\times 100$

\subsubsection{Hemolysis assay}

Peptide nanotubes were assayed spectrophotometrically for their ability to induce hemoglobin release from fresh equine erythrocytes according to the method previously utilized by our group [22]. Fresh defibrinated equine erythrocytes were washed three times with equal volumes of PBS. After centrifugation for 15 minutes at $900 \mathrm{~g}$, erythrocytes were resuspended $4 \%$ v/v in PBS. Equal volumes $(100 \mu \mathrm{L})$ of the erythrocyte suspension were added to each well of a 96-well microtiter plate. Erythrocytes were subsequently exposed to varying concentrations of peptide, incubated at $37^{\circ} \mathrm{C}$ for 1 hour and centrifuged at $1000 \mathrm{~g}$ for five minutes. Aliquots of the supernatant were transferred to a fresh 96-well microtiter plate, and hemoglobin release measured spectrophotometrically at $405 \mathrm{~nm}$ using a Tecan 
Sunrise plate reader (Tecan UK Ltd, Reading, UK). As a positive control (100\% hemolysis), erythrocytes were treated with $0.1 \%$ Triton X-100, whilst PBS ( $0 \%$ hemolysis) acted as a negative control. Results for all concentrations are reported as the mean of three replicated assays with six repeats at each concentration. Percentage hemolysis was calculated as follows:

$\%$ Hemolysis $=\frac{\text { Absorbance } 405 \mathrm{~nm} \text { peptide }- \text { Absorbance } 405 \mathrm{~nm} \text { PBS }}{\text { Absorbance } 405 \mathrm{~nm} 0.1 \% \text { Triton X }- \text { Absorbance } 405 \mathrm{~nm} \text { PBS }} \times 100$

Equation 2

\subsubsection{Bacterial (planktonic) susceptibility assays}

The ability of peptide nanotubes to reduce bacterial viability and inhibit growth was adopted from a method previously used by our group [23]. S. aureus NCTC 10788, S. epidermidis ATCC 12228, P. aeruginosa ATCC 15692 and E. coli ATCC 15597 were inoculated from cryogenic storage beads and allowed to grow for $18-24$ hours at $37^{\circ} \mathrm{C}$ in Lysogeny broth (LBB). The optical density was adjusted to 0.3 at $550 \mathrm{~nm}$, corresponding to $1 \times 10^{8} \mathrm{CFU} / \mathrm{mL}$, using PBS. A further 1 in 50 dilution was carried out in LBB, to prepare a working suspension of bacteria, and $100 \mu \mathrm{L}$ of this was added to a 96-well microtiter plate and challenged with a range of concentrations $(10 \mathrm{mg} / \mathrm{mL}$ to $0.625 \mathrm{mg} / \mathrm{mL})$ of peptide nanotube suspensions. The positive control well consisted of $100 \mu \mathrm{L}$ of the working bacteria suspension and $100 \mu \mathrm{L}$ of the UltraPure ${ }^{\mathrm{TM}}$ DNase/RNase-free distilled water. The negative control consisted of $100 \mu \mathrm{L}$ of sterile LBB and $100 \mu \mathrm{L}$ of UltraPure ${ }^{\mathrm{TM}}$ DNA/RNA free sterile distilled water. The challenge plates, containing peptide nanotubes, were incubated for 24 hours at $37{ }^{\circ} \mathrm{C}$ and viable counts obtained via Miles and Misra counting. $\mathrm{NH}_{2}-\mathrm{FF}-\mathrm{NH}_{2}$ were not tested against S. epidermidis ATCC 12228 and P. aeruginosa ATCC 15692 due to lack 
of efficacy against model Gram-positive S. aureus NCTC 10788 and Gram-negative E. coli ATCC 15597. Results were displayed as the mean $\left(\log _{10} \mathrm{CFU} / \mathrm{mL}\right)$ of three replicates and tests were performed as triplicate.

\subsubsection{MBEC (biofilm) high-throughput assay ${ }^{\mathrm{TM}}$}

The activity of the peptide nanotubes against mature biofilms was tested using an MBEC assay $^{\text {TM }}$. S. aureus NCTC 10788 and E. coli ATCC 15597 were selected as model Grampositive and Gram-negative bacterial isolates based on the ability of these strains to form strongly adherent biofilms within 24 hours and their negative impact within healthcare [24, 25]. The assay is performed as previously outlined by our group [22] and is detailed fully within the supporting information (section S2). A modified 96-well plate, termed the MBEC plate, has polystyrene pegs attached to the lid allowing reproducible growth of biofilms on each peg. The MBEC value, corresponding to the minimum concentration of antimicrobial that leads to complete eradication of biofilm after 24 hours exposure, is determined via Miles and Misra viable colony counts.

\subsubsection{Outer membrane bacterial permeability assay}

NPN is a fluorescent probe that exhibits weak fluorescence in an aqueous environment, with increasing fluorescence intensity upon transition to a hydrophobic environment. An increase in the outer membrane permeability of a Gram-negative bacterial cell allows NPN to permeate into the inner hydrophobic membrane and enables an increase in fluorescence signalling. To prepare Gram-negative bacteria (E. coli ATCC 15597 and P. aeruginosa ATCC 15692) for the NPN assay, $25 \mathrm{~mL}$ of broth from an overnight culture was centrifuged at $5000 \mathrm{~g}$ to form a pellet of viable bacteria cells. The supernatant was removed to discard the non-viable cells from the sample. This pellet was resuspended in HEPES buffer ( $5 \mathrm{mM})$ and the OD adjusted to $0.3 \pm 0.02$. The experiment was carried out in a 96-well microtiter 
plate, with $50 \mu \mathrm{L}$ of $1 \times 10^{8} \mathrm{CFU} / \mathrm{mL}(0.3 \mathrm{OD}$ adjusted) $E$. coli and $50 \mu \mathrm{L}$ of NPN solution in HEPES (40 microM) added to each experimental and control well. The bacteria were challenged with $100 \mu \mathrm{L}$ of peptide nanotube suspensions $(10 \mathrm{mg} / \mathrm{mL}$ to $0.625 \mathrm{mg} / \mathrm{mL})$ of either $\mathrm{NH}_{2}-\mathrm{FF}-\mathrm{COOH}$ or $\mathrm{NH}_{2}-\mathrm{ff}-\mathrm{COOH}$ peptide, prepared as described above. $100 \mu \mathrm{L}$ of the Gram-negative selective antibiotic polymyxin B (100 mM) was used as the positive control (100 \% NPN uptake reference) as previously described [26]. $100 \mu \mathrm{L}$ of HEPES buffer (5 $\mathrm{mM}$ ) was added to the negative control well to make a consistent volume of $200 \mu \mathrm{L}$ in all wells. Fluorescence intensity of all wells was measured every 60 seconds for 5 minutes at excitation/emission wavelengths 340/457 nm. After subtracting the background (HEPES buffer, NPN with bacteria), fluorescence intensities were compared against the polymyxin B control $(100 \mathrm{mM})$ to calculate $\%$ of NPN uptake. Experiments were perfomed as triplicate with three replicates for each variable..

$$
\% \text { NPN uptake }=\frac{\text { Peptide treated fluorescence-background }}{\text { Polymyxin B fluorescence-background }}
$$

\subsubsection{SEM biofilm imaging}

SEM was used to investigate the appearance of the biofilm after treatment with peptide, as previously described [27]. To prepare the pegs, covered in mature 24 hour biofilms of $S$. aureus NCTC 10788, and E. coli ATCC 15597, for imaging they were fixed in $2.5 \%$ glutaraldehyde in $0.1 \mathrm{M}$ cacodylic acid $\left(\mathrm{pH} \mathrm{7.2)}\right.$ at $4{ }^{\circ} \mathrm{C}$ for 16 hours after previously being rinsed twice in PBS to remove non-adhered planktonic bacteria. Following this, the pegs were rinsed in $0.1 \mathrm{M}$ cacodylic acid $(\mathrm{pH}$ 7.2) for 10 minutes, and then in double distilled water for 10 minutes. Immediately after, the samples were dehydrated by immersing sequentially in $50 \%, 70 \%, 90 \%$ and $100 \%$ ethanol for 30 minutes. After air-drying for 48 
hours at room temperature, the samples were mounted on aluminium stubs using fast drying epoxy resin and gold spluttered in pure gold before SEM imaging.

\subsubsection{Statistical methods}

Statistical analyses were performed using Microsoft Excel 2013 and GraphPad Prism 6. Standard deviations were obtained at each concentration of peptide nanotube tested based on three replicates for quantitative bacterial viability assays and mean values obtained. Statistical analyses were employed using a one way Analysis of Variance (ANOVA) with a Tukey's multiple comparisons test used to identify individual differences between the reduction in bacterial viability (planktonic and biofilm) for each peptide nanotube relative to the negative bacterial growth control. MTS and hemolysis data was compared by the same statistical method, with percentage cell viability and hemolysis compared to the media only (100\% cell viability) and PBS non-hemolytic negative controls. One way ANOVA were employed as data was shown to be normally distributed using the Kolmogorov and Smirnov method. In all cases a probability of $p<0.05$ denoted significance.

3. Results and discussion.

\subsection{Peptide nanotube formulation and morphology}

The majority of previous research has focused on using highly toxic organic solvents, such as hexafluoro-2-propanol (HFIP) and methanol, to formulate and permit complete dissolution of FF molecules. In these examples FF nanotube formation proceeds via subsequent dilution in water [28]. Our group was able to form defined nanotube structures $(163.7 \pm 31.8 \mathrm{~nm}$ in diameter, Figure 2) for all three peptides at concentrations of $1 \mathrm{mg} / \mathrm{mL}$ and above using Ultrapure ${ }^{\mathrm{TM}}$ water as a formulation medium and heating to $65^{\circ} \mathrm{C}$, then cooling to room temperature (Table 1) [20]. This is a significant advantage in the preparation of FF 
nanotubes, in order to reduce potential for solvent induced toxicity. This is a key consideration for the future translation of this technology in a drug delivery and healthcare setting.
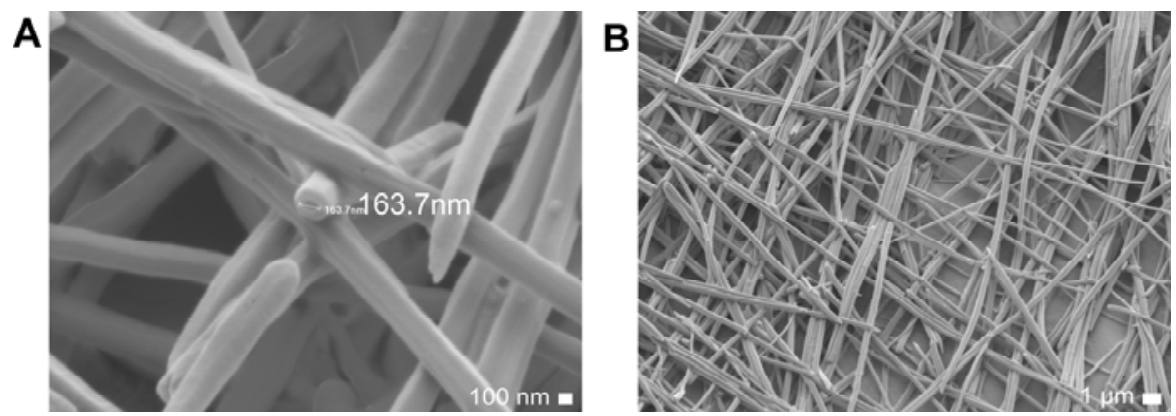

Figure 2. SEM images of $1 \mathrm{mg} / \mathrm{mL} \mathrm{NH}_{2}-\mathrm{FF}-\mathrm{COOH}$ nanotube structures at (A) $30,000 \mathrm{x}$ magnification, scale bar $=100 \mathrm{~nm},(B) 4,000 x$ magnification, scale bar $=1 \mu \mathrm{m}$.

\subsection{Cell cytotoxicity and viability}

Cell viability (LIVE/DEAD® staining, MTS) assays confirm that both $\mathrm{NH}_{2}-\mathrm{FF}-\mathrm{COOH}$ and its d-enantiomeric equivalent $\mathrm{NH}_{2}$-ff- $\mathrm{COOH}$ exhibit minimal toxicity (Figures $3,4, \mathrm{~S} 4$ ) to subcutaneous fibroblast cells (NCTC clone 929, ATCC® CCL-1) at concentrations studied ( $\leq 10 \mathrm{mg} / \mathrm{mL}$ ). These include concentrations that completely eradicate staphylococcal biofilms $\left(\mathrm{NH}_{2}-\mathrm{FF}-\mathrm{COOH}\right.$ and $\mathrm{NH}_{2}$-ff-COOH: $\left.10 \mathrm{mg} / \mathrm{mL}\right)$. Interestingly the increased cationicity provided by an extra terminal amine within $\mathrm{NH}_{2}-\mathrm{FF}-\mathrm{NH}_{2}$ is sufficient to result in toxicity at concentrations greater than or equal to $2.5 \mathrm{mg} / \mathrm{mL}$ as observed by LIVE/DEAD® (Figure 3) and MTS (Figure 4A) assays. FF nanotubes also demonstrate minimal toxicity against mammalian membranes using a hemolysis assay (Figure 4B). Each peptide demonstrated no significant hemolysis when compared to the negative PBS control. Figure 
3A also demonstrates FF nanotubes are able to retain their nanotube architecture within tissue culture media, at conditions $(\mathrm{pH}$, temperature, ionic strength) that mimic the physiological environment. However further long-term stability studies are required to elucidate their wider potential as pharmaceuticals [29]

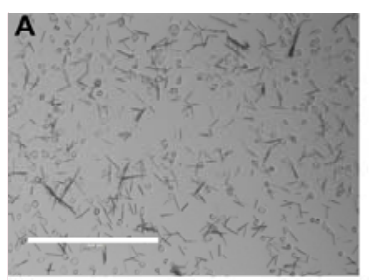

B

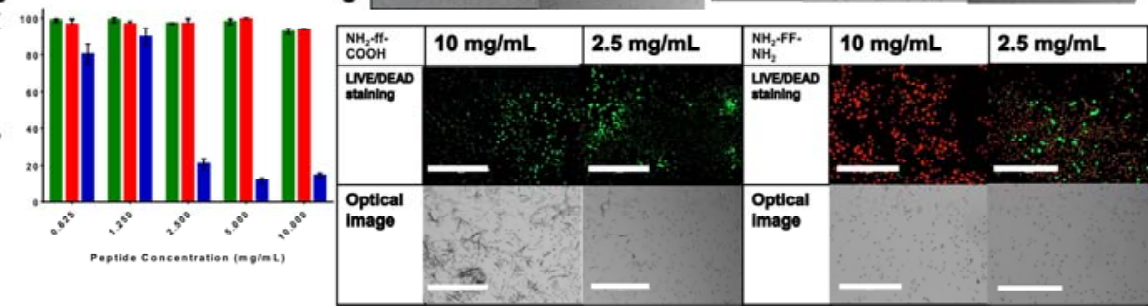

Figure 3. A) Optical image of NCTC 929 cells with $\mathrm{NH}_{2}-\mathrm{ff}-\mathrm{COOH}$ nanotubes. B) Quantitative cell counting analysis of LIVE/DEAD® stain after exposure to varying concentrations of $\mathrm{NH}_{2}$ FF-COOH (green), $\mathrm{NH}_{2}$-ff- $\mathrm{COOH}$ (red) and $\mathrm{NH}_{2}-\mathrm{FF}-\mathrm{NH}_{2}$ (blue). Counts taken from three randomly selected areas with total cell count of 200. C) LIVE/DEAD® fluorescent and optical images of NCTC 929 cells with varying concentrations of: $\mathrm{NH}_{2}-\mathrm{FF}-\mathrm{COOH}, \mathrm{NH}_{2}-\mathrm{ff}-\mathrm{COOH}$ and $\mathrm{NH}_{2}-\mathrm{FF}-\mathrm{NH}_{2}$ peptide nanotubes, positive ( $70 \%$ ethanol) and negative (media only) controls. Green staining indicates live cells, red staining indicates dead cells. Each image taken after 6 hours incubation with dipeptide nanotube, scale bar key: white line $=200 \mu \mathrm{m}$, blue line $=$ $400 \mu \mathrm{m}$.
Commented [GL2]: Figure 3 now deleted and incorporated into previous Figure 4 as recommended

Commented [GL3]: New Figure 3 based on modified recommendations to previous figure 4

Commented [GL4]: LIVE/DEAD data taken from SI and placed here, positive and negative controls included as (B), LIVE/DEAD counts quantified as (C). Image quality enhanced using ImageJ. Scale bars improved and now include color coding in captions. 

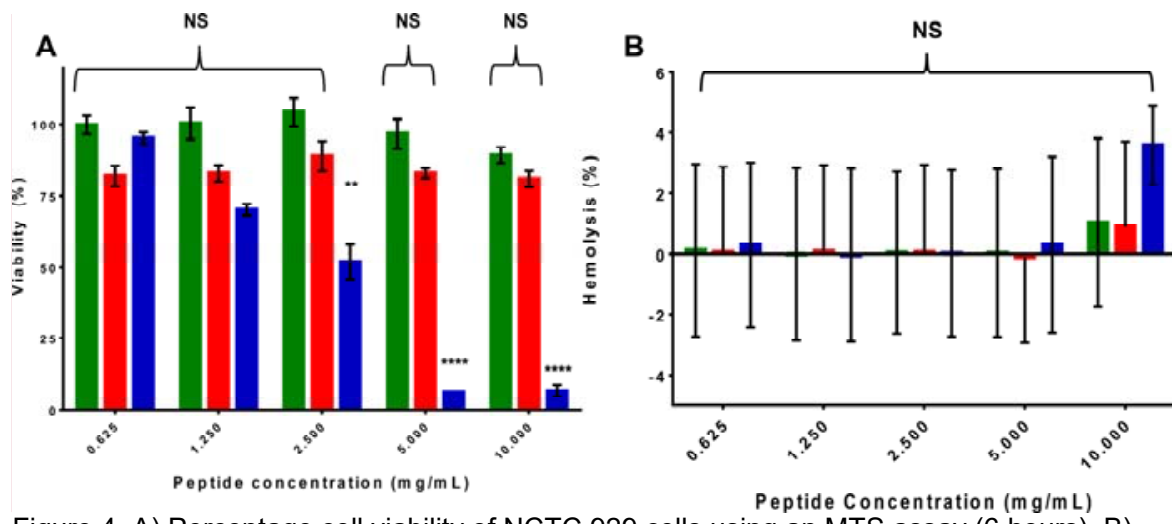

Commented [GL5]: MTS viability study included (A).
Hemolysis data now converted to a GraphPad derived figure to keep data presentation consistent.

Figure 4. A) Percentage cell viability of NCTC 929 cells using an MTS assay (6 hours), B)

percentage hemolysis of equine erythrocytes (1 hour), after exposure to varying concentrations of $\mathrm{NH}_{2}-\mathrm{FF}-\mathrm{COOH}$ (green), $\mathrm{NH}_{2}-\mathrm{ff}-\mathrm{COOH}$ (red) and $\mathrm{NH}_{2}-\mathrm{FF}-\mathrm{NH}_{2}$ (blue). Key: NS: no significant $(p \geq 0.05),{ }^{* *}: p<0.01,{ }^{* * *}: p<0.0001$ difference between the peptide nanotubes and the negative control $(A=$ media only, $B=P B S)$.

\subsection{Planktonic and biofilm bacterial susceptibility}

Bacterial susceptibility assays were performed initially against planktonic forms of microorganisms widely implicated in bacterial infectious disease. These were, Gram-positive S. aureus NCTC 10788 and S. epidermidis ATCC 12228, and Gram-negative E. coli ATCC 15597 and $P$. aeruginosa PA01 (Figure 5C-F). From these preliminary studies it was evident that $\mathrm{NH}_{2}-\mathrm{FF}-\mathrm{COOH}$ was the most potent antibacterial nanotube demonstrating greater than $3 \log _{10}$ reduction in colony forming units per milliliter (CFU/mL), equivalent to higher than 99.9\% decrease, at $5 \mathrm{mg} / \mathrm{mL}$ and complete bactericidal kill at $10 \mathrm{mg} / \mathrm{mL}$ against planktonic Gram-positive S. aureus and S. epidermidis (Figures $5 \mathrm{C}$ and 5D). $\mathrm{NH}_{2}-\mathrm{FF}-\mathrm{COOH}$ was less active against Gram-negative bacteria (Figures $5 \mathrm{E}$ and $5 \mathrm{~F}$ ) failing to achieve bactericidal activity at $10 \mathrm{mg} / \mathrm{mL}$ but still demonstrating $3 \log _{10}$ reduction (99.9\%), a clinical milestone for inhibitory action, at this concentration [30]. Reduced efficacy in Gram-negative bacteria is 
likely due to differences in the membrane architecture. Gram-negative bacteria possess an extra outer lipopolysaccharide membrane that limits influx and uptake of antibiotic molecules [31]. This outer membrane has proven to be a major obstacle in antibiotic uptake, treatment efficacy and drug development within Gram-negative infections [32]. The ability of the most promising peptide nanotube, $\mathrm{NH}_{2}-\mathrm{FF}-\mathrm{COOH}$, to permeate the outer lipopolysaccharide membrane was studied using NPN as a fluorescent probe to indicate whether the Gramnegative membrane is compromised in E.coli and $P$. aeruginosa [26]. In the presence of 10 $\mathrm{mg} / \mathrm{mL} \mathrm{NH} \mathrm{N}_{2}-\mathrm{FF}-\mathrm{COOH}$ and $\mathrm{NH}_{2}-\mathrm{ff}-\mathrm{COOH}$, Gram-negative bacteria show increased NPN uptake, demonstrating similar efficacy $(\sim 100 \%)$ of NPN uptake relative to polymyxin B positive control (Figure S5, S6). Such uptake is sufficient to allow significant bactericidal activity in planktonic forms of $E$. coli and $P$. aeruginosa but not within Gram-negative biofilms.

The ability of FF nanotubes to kill mature surface-attached bacterial biofilm forms is more relevant to clinical infections and we studied this phenomenon using a MBEC assay ${ }^{\mathrm{TM}}$. Biofilms of each bacteria were grown on polystyrene pegs for 24 hours. Despite biofilm forms being associated with increased tolerance to antibiotics, requiring 10 to 1000 times antibacterial concentrations to achieve equivalent planktonic efficacy [3], $\mathrm{NH}_{2}-\mathrm{FF}-\mathrm{COOH}$ was able to obtain greater than $3 \log _{10} \mathrm{CFU} / \mathrm{mL}$ reduction at $5 \mathrm{mg} / \mathrm{mL}$ and a MBEC value (total biofilm kill) of $10 \mathrm{mg} / \mathrm{mL}$ against $S$. aureus biofilms after 24 hours (Figure $5 \mathrm{~A}$ ). This is equivalent to its efficacy against planktonic forms of staphylococci (Figure 7C and D).

At concentrations of $5 \mathrm{mg} / \mathrm{mL}$ the L-enantiomeric FF variant $\left(\mathrm{NH}_{2}-\mathrm{FF}-\mathrm{COOH}\right)$ demonstrated improved antibiofilm activity against $S$. aureus biofilm relative to the D-variant (Figure 5A). The increased biofilm potency of our $\mathrm{NH}_{2}-\mathrm{FF}-\mathrm{COOH}$ was also observed for planktonic forms of S. aureus (Figure 5C) and Gram-negative pathogens tested (Figure 5E and 5F). This is an interesting result that opposes what has been observed in several recent studies relating to L, D structural confirmation and biofilm activity. Previous reports have demonstrated that Dforms of amino acids, including phenylalanine, act as biofilm dispersal agents and enhance 
the activity of standardly employed colistin and ciprofloxacin against $P$. aeruginosa biofilms and rifampicin against S. aureus [33]. Manabe and colleagues compared the antimicrobial properties of $\mathrm{D}$ - and L-forms of KLKLLLLLKLK-NH $\mathrm{N}_{2}$, a sequence derived from the antimicrobial peptide sapesin B [34]. They discovered that the D-enantiomer demonstrated higher affinity for bacterial cell wall components, such as peptidoglycan in S. aureus, and that this served as a potential means to improve transfer of peptide to the bacterial plasma membrane, resulting in improved antibacterial potency. There are more widespread reports in the literature that biological enhanced activity is due to increased resistance of $D$-isomers to bacterial proteases released in vitro rather than specific stoichiometric targeting [35].

Whilst such studies are suggesting a link between enantiomeric confirmation and antibiofilm activity in peptides the overall picture is inconclusive with the vast majority of studies demonstrating no significant differences in $\mathrm{D}, \mathrm{L}$ configuration and antibiofilm activity. Therefore further investigations of such a link are warranted within our low molecular weight motifs. The study of the differences in short-range molecular interactions between L, Denantiomers and bacterial cell surface components is in its infancy, especially for ultrashort peptides, and requires further characterisation before this can be conclusively reported.
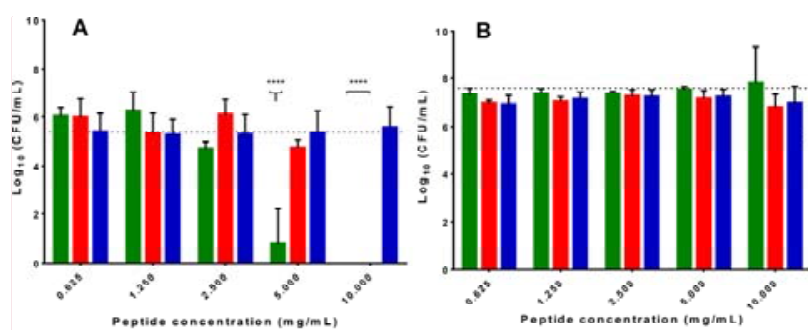

C $\quad \dot{*} \quad \ldots \ldots$
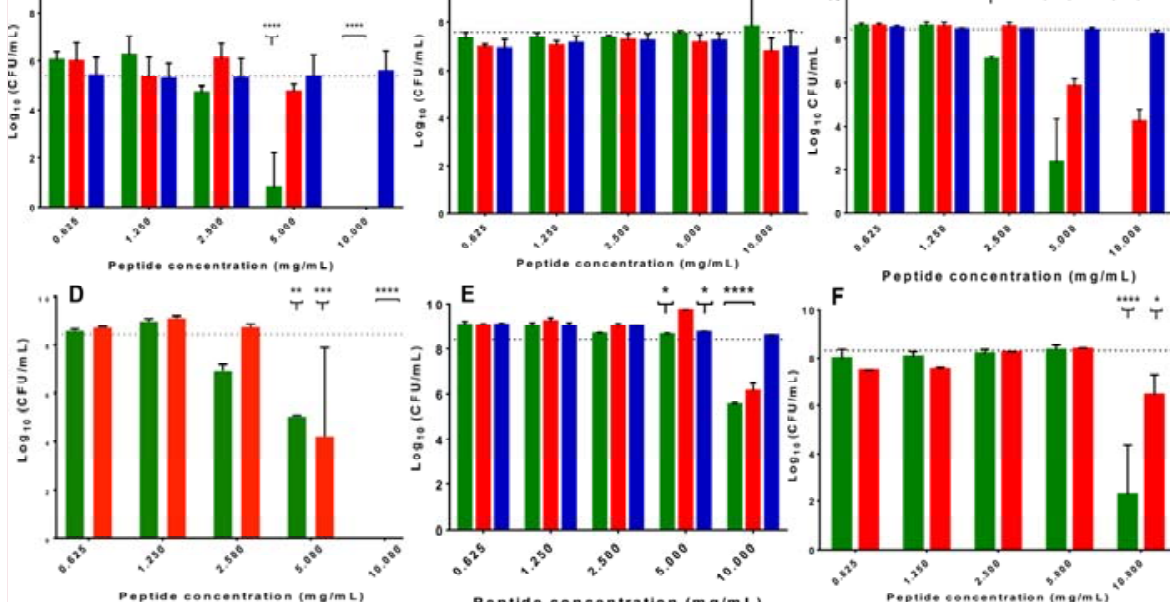
$\mathbf{F}$

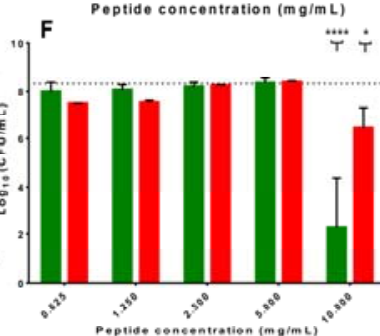

Commented [GL6]: Planktonic data (C-F) from SI now included within one figure. A) First bar now changed from red to green as it was incorrectly labelled red (signifying D isomer) in original submission 
Figure 5. Biofilm and planktonic viability counts $\left(\log _{10} \mathrm{CFU} / \mathrm{mL}\right)$ after 24 hours exposure to $\mathrm{NH}_{2}-\mathrm{FF}-\mathrm{COOH}$ (green), $\mathrm{NH}_{2}$-ff- $\mathrm{COOH}$ (red) and $\mathrm{NH}_{2}-\mathrm{FF}-\mathrm{NH}_{2}$ (blue) to mature (24 hour) biofilms of (A) S. aureus NCTC 10788 (B) E. coli ATCC 15597, planktonic (C) S. aureus NCTC 10788, (D) S. epidermidis ATCC 12228, (E) E. coli ATCC 15597, (F) P. aeruginosa ATCC 15692. Dotted line represents negative growth control (bacteria only), *: $p<0.05,{ }^{* *}$ : $p<0.01,{ }^{* *}: p<0.001,{ }^{* * * *}: p<0.0001$ significant difference between $\log _{10} C F U / m L$ of peptide nanotube treatment and the negative control.

Due to its amphipathic nature, $\mathrm{NH}_{2}$-FF-COOH's mechanism of action was hypothesized to be via formation of ion channels in bacterial membranes and/or a surfactant-like disintegration of the biofilm exo-polysaccharide architecture and bacterial cell membranes as previously observed for a variety of naturally occurring antimicrobial peptide motifs and peptide nanotube structures [21,36-38], This was later confirmed and shown to be concentration dependent via SEM analysis (Figure 6B, Figure S7). $\mathrm{NH}_{2}-\mathrm{FF}-\mathrm{COOH}$ was able to selectively disrupt the peptidoglycan cell wall and cytoplasmic lipid membrane of Grampositive $S$. aureus resulting in cell lysis and death. Targeting of bacterial membranes is a preferred mode of action compared to blocking single biomolecular pathways as it is more difficult for bacteria to develop resistance via minor modification of an important enzyme or signaling pathway. Although incidences of resistance have been reported due to alteration of specific membrane bound receptors in Gram-negative species [39], the entire structure of the bacterial membrane would have to be modified in order to completely negate surfactantlike activity [37]. However, no significant reduction was observed for Gram-negative biofilms at concentrations employed (Figures 5B). No pore-like structures were observed in the outer envelope of Gram-negative E.coli (Figure 6D) suggesting membrane damage did not occur. The reduction in activity of $\mathrm{NH}_{2}-\mathrm{FF}-\mathrm{COOH}$ against Gram-negative biofilms compared to planktonic forms is due to difficulty permeating the biofilm matrix, which is primarily composed of polyanionic alginate ( $P$. aeruginosa) or colanic acid (E. coli) that acts as a 
sponge to block diffusion of amphipathic and cationic peptides [40]. This ability may be especially relevant to negating the antibacterial activity of cationic $\mathrm{NH}_{2}-\mathrm{FF}-\mathrm{NH}_{2}$.

Whilst conclusive evidence for antimicrobial peptide selectivity for bacterial over mammalian cells is still forthcoming, there is an acceptance amongst researchers that physiochemical properties, especially amphiphilicity, are of significant importance given that the vast majority of antimicrobial peptides contain hydrophobic and charged regions [37, 41]. Such characteristics are important for peptides which are membrane active, either enabling cell entry for intracellular targeting or membrane disruption. Regardless, the difference in bacterial (cell wall and membrane) and mammalian membrane architecture plays a key role in antimicrobial peptide cell selectivity given that this is the first structure the peptide will encounter upon exposure to cells. A large proportion of bacterial cell membranes are composed of acidic phospholipids, such as cardiolipin and phosphatidylglycerol, leading to an overall net negative charge [42]. Bacterial cell walls also contain large amounts of anionic components including teichoic acids and lipoteichoic which form part of the peptidoglycan of Gram-positive bacteria. Lipopolysaccharides present in the outer membrane of Gramnegative bacteria are also anionic [43]. Mammalian cell membranes however possess a net neutral charge due to the presence of zwitterionic phosphatidylcholine and sphingomyelin in the outer membrane surface [44]. Cholesterol, which itself is neutrally charged, plays an important role in membrane stabilization against antimicrobial peptide attack and has been shown to increase the stiffness and cohesiveness of the lipid bilayer membrane [45]. Most anionic phospholipids tend to be unexposed, enclosed within the inner surface of the plasma membrane [43].

Taking into account the above factors that are deemed to govern antimicrobial peptide activity, it would be expected that increasing the cationic charge of FF via substitution of a carboxylic acid with an amide would be favourable to improved selectively for bacterial cell membranes. However, the exact mechanism by which amphipathic antimicrobial peptides mediate membrane disruption remain unclear as the exact conformation such peptides in 
bacterial and mammalian membranes is unknown. The hydrophobic: charge balance is extremely important for large molecular weight, naturally occurring antimicrobial peptides but it is especially significant in ultrashort peptide systems ( $\leq 7$ amino acids) whereby change in one amino acid unit or functional group can result in hydrophobic: charge imbalance, compromising activity or leading to increased mammalian cell cytotoxicity $[37,46]$. Substantial increase or decrease in amphipathicity, charge, hydrophobic characteristics have been observed to cause similar effects [44].

For the FF motif, it is possible that substitution of the carboxylic acid functional group in $\mathrm{NH}_{2}-$ FF-COOH and $\mathrm{NH}_{2}-\mathrm{ff}-\mathrm{COOH}$ with an amide moiety $\left(\mathrm{NH}_{2}-\mathrm{FF}-\mathrm{NH}_{2}\right)$ is sufficient to increase cationicity, resulting in a shift in the hydrophobic: charge balance, leading to significant mammalian cell toxicity and lowered antimicrobial potency within this low molecular weight dipeptide system. This is demonstrated by a change in the predicted physiochemical properties for $\mathrm{NH}_{2}-\mathrm{FF}-\mathrm{NH}_{2}$ at a formulated $\mathrm{pH}$ of 7 , where it possesses an apparent overall charge of +0.836 and LogD of 0.606 (LogP: 1.39) (Table S1). Unsurprisingly both L and D carboxylic acid terminated FF variants $\left(\mathrm{NH}_{2}-\mathrm{FF}-\mathrm{COOH}\right.$ and $\left.\mathrm{NH}_{2}-\mathrm{ff}-\mathrm{COOH}\right)$ share similar physiochemical characteristics, possessing a predicted LogD of -0.099 and a relatively neutral charge (-0.08). However, it must be emphasised these are only predicted values for physiochemical properties, serving as a useful tool for approximating the hydrophobic: charge balance and antimicrobial effects. Recent research in self-assembling peptide hydrogelator systems have demonstrated a link between self-assembly and changes in physiochemical properties, such as pKa [47]. Whilst this has not been explicitly linked to selfassembling nanotube systems, there may be a similar effect, adding a further layer of complexity to predicting antimicrobial activity for self-assembling peptides. Nonetheless it serves as an interesting area for further study.

The presence of self-assembly has also been specifically linked to providing antimicrobial activity in peptide-based systems [48]. FF forms the fundamental self-assembly motif of $\beta$ amyloid, the main component of plaques linked to Alzheimer's and type-2 diabetes [49]. $\beta$ - 
amyloid also demonstrates antimicrobial activity and the ability to form transmembranous pores in bacterial and mammalian cells, suggesting a connection between assembly, folding, structural conformation and its mode of antimicrobial action $[50,51]$. To our knowledge, the FF peptide motif does not have any specific enzymatic targets, therefore antibacterial activity may due to surfactant-like action on bacterial membranes and biofilms and/or the formation of ion channels by FF nanotubes resulting in membrane depolarisation as observed for $\beta$ amyloid peptides [52]. Self-assembling FF systems has also been recently associated with bacterial membrane depolarization, inducing the upregulation of stress response regulons, resulting in severe bacterial cell damage [21]. However, more studies must be performed to explicitly link self-assembly of aromatic short peptide derivatives to antibacterial and antibiofilm activity, especially in relation to membrane interactions, structural assembly, presentation of functional groups and molecular modelling. This will enable tailoring of the FF peptide structure to improve antimicrobial selectivity and spectrum of activity. 

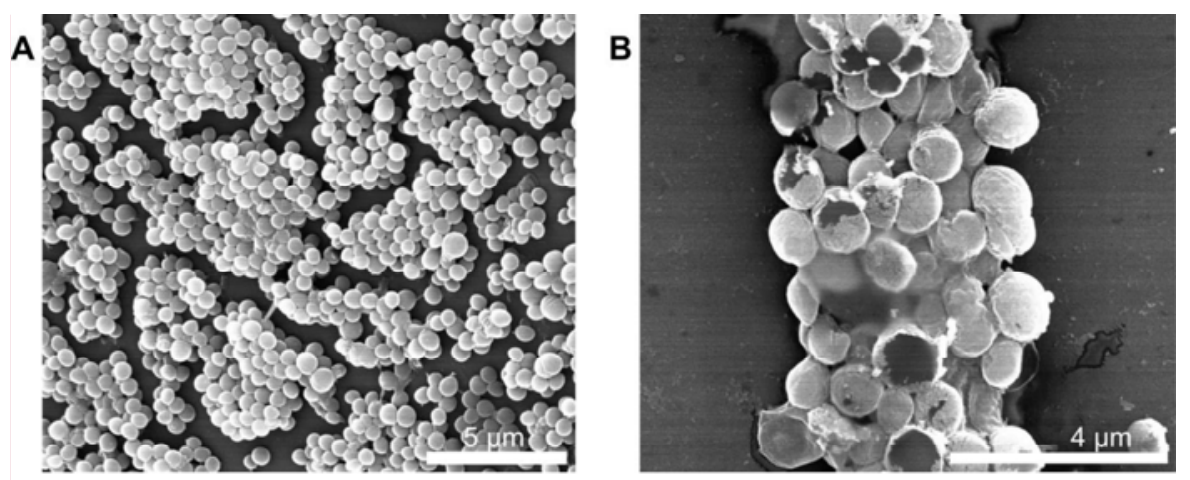

Commented [GL7]: Black borders removed. Scale bars improved.
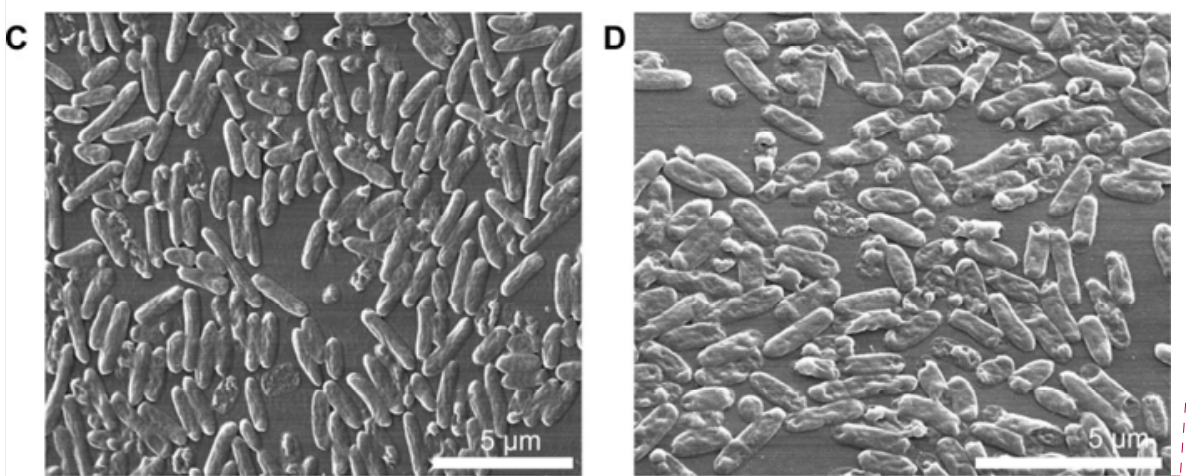

Figure 6. SEM images of (A) $15,000 x$ magnification untreated 24 hour mature $S$. aureus

NCTC 10788 biofilm on MBEC peg, scale bar $=5 \mu \mathrm{m}$. (B) 30,000x magnification S. aureus

NCTC 10788 biofilm after 24 hour treatment with $2.5 \mathrm{mg} / \mathrm{mL} \mathrm{NH}_{2}-\mathrm{FF}-\mathrm{COOH}$, scale bar $=4$

$\mu \mathrm{m}$. (C) 15,000x magnification untreated 24 hour mature E. coli ATCC 15597 on MBEC peg, scale bar $=5 \mu \mathrm{m}$. (D) 20,000x magnification mature E. coli ATCC 15597 biofilm after 24 hour treatment with $2.5 \mathrm{mg} / \mathrm{mL} \mathrm{NH}_{2}-\mathrm{FF}-\mathrm{COOH}$, scale bar $=5 \mu \mathrm{m}$.

\section{Conclusions}

In conclusion, we demonstrate $\mathrm{NH}_{2}-\mathrm{FF}-\mathrm{COOH}$ to be a promising peptide nanomaterial to target Gram-positive biofilm infection and of potential use as a future therapy in the treatment of medical device, bone and wound infections attributed with high rates of treatment failure and antibiotic resistance due to the presence of staphylococcal biofilms. 
Despite being neutrally charged $\mathrm{NH}_{2}-\mathrm{FF}-\mathrm{COOH}$ and $\mathrm{NH}_{2}$-ff- $\mathrm{COOH}$ nanotubes are able to selectively target bacterial cell membranes and permeate the biofilm matrix via a surfactantlike mechanism, resulting in total biofilm eradication at $10 \mathrm{mg} / \mathrm{mL}$. This may also due to their ability of self-assembled FF sequences to form ion channels in bacterial cell membranes mimicking those observed recently for $\beta$-amyloid. Both $\mathrm{NH}_{2}-\mathrm{FF}-\mathrm{COOH}$ and $\mathrm{NH}_{2}$-ff- $\mathrm{COOH}$ nanotubes have minimal toxic effects on mammalian cells highlighting further their potential to be clinically translated. Further studies will focus on formulation and stability of $\mathrm{NH}_{2}-\mathrm{FF}-$ $\mathrm{COOH}$ for delivery to medical device, bone and wound sites. Despite the relative lack of activity against biofilms of $E$. coli, $\mathrm{NH}_{2}-\mathrm{FF}-\mathrm{COOH}$ and $\mathrm{NH}_{2}$-ff- $\mathrm{COOH}$ nanotubes did demonstrate an ability to penetrate the outer membrane of Gram-negative bacteria as observed via a NPN assay. Whilst this did not result in bacterial cell death in biofilm forms, it is an important observation. Molecules with the ability to cross or disrupt the outer membrane of Gram-negative biofilm bacteria have the potential to be utilized synergistically to repurpose licensed antibiotics that target the peptidoglycan inner layer and tend to be Gram-positive selective, for example the glycopeptide vancomycin or the macrolide erythromycin. They may also lower the effective therapeutic dose of antibiotics currently licensed to treat Gram-negative biofilms, reducing side effects to the patient and development of antimicrobial resistance. The architecture of these peptide nanostructures mean antibiotics could be potentially encapsulated within the hollow hydrophilic pores of FF nanotubes or within their hydrophobic phenylalanine walls. Nanotubes have previously been explored for drug delivery purposes and because of $\mathrm{NH}_{2}-\mathrm{FF}-\mathrm{COOH}$ and $\mathrm{NH}_{2}$-ff-COOH's selectivity for bacterial cells they are worthy of further exploration as an antibiofilm drug delivery platform.

\section{Abbreviations}


$\mathrm{CFU} / \mathrm{mL}$, colony forming units per milliliter; FF, diphenylalanine; HFIP, hexafluoro-2propanol; MBEC, minimum biofilm eradication concentration; NPN, N-phenyl-1naphthylamine.

\section{Acknowledgements}

This work was supported by Royal Society (IE160988 and RG150171) and Wellcome Trust (207618/Z/17/Z) research grants for GL. We wish to acknowledge the use of Chemicalize software (ChemAxon) via the EPSRC funded National Chemical Database Service hosted by the Royal Society of Chemistry.

Tables

Table 1. Stepwise formulation of self-assembling dipeptide nanotubes.

\begin{tabular}{|c|c|}
\hline Formulation step & Method employed \\
\hline 1 & $\begin{array}{l}\text { Weigh out appropriate amount of peptide } \\
\qquad(\text { e.g. } 10 \mathrm{mg})\end{array}$ \\
\hline 2 & $\begin{array}{l}\text { Add UltraPure }{ }^{\mathrm{TM}} \text { DNase/RNase-free distilled } \\
\text { water until desired concentration }(1-10 \\
\mathrm{mg} / \mathrm{ml}) \text { and vortex thoroughly for } 30 \text { seconds }\end{array}$ \\
\hline 3 & Heat at $65^{\circ} \mathrm{C}$ for 30 minutes \\
\hline 4 & Anneal to room temperature \\
\hline 5 & $\begin{array}{l}\text { Leave for } 24 \text { hours at ambient conditions to } \\
\text { allow self-assembly to occur }\end{array}$ \\
\hline 6 & $\begin{array}{l}\text { Titrate to } \mathrm{pH} 7 \pm 0.2 \text { with } \sim 20 \mu \mathrm{L} \text { of } 1 \mathrm{M} \\
\qquad \mathrm{NaOH} \text { solution }\end{array}$ \\
\hline
\end{tabular}

\section{References}


[1] Joo HS, Otto M. Molecular basis of in vivo biofilm formation by bacterial pathogens. Chem Biol 2012;19:1503-1513.

[2] Macia MD, Rojo-Molinero E, Oliver A. Antimicrobial susceptibility testing in biofilmgrowing bacteria. Clin Microbiol Infect 2014;20:981-990.

[3] Simoes M. Antimicrobial strategies effective against infectious bacterial biofilms. Curr Med Chem 2011;18:2129-2145.

[4] Chiang WC, Nilsson M, Jensen PO, Hoiby N, Nielsen TE, Givskov M, Tolker-Nielsen T. Extracellular DNA shields against aminoglycosides in Pseudomonas aeruginosa biofilms. Antimicrob Agents Chemother 2013;57:2352-2361.

[5] Stalder T, Top E. Plasmid transfer in biofilms: a perspective on limitations and opportunities. NPJ Biofilms Microbiomes 2016;2:10.1038/npjbiofilms.2016.22. Epub 2016 Oct 19 .

[6] O'Neill J. The Review on Antimicrobial Resistance: UK Government Report. The Review on Antimicrobial Resistance 2015;

[7] Centers for Disease Control and Prevention (CDC). National action plan for combating antibiotic-resistant bacteria. 2015;.

[8] Laverty G, McCloskey AP, Gilmore BF, Jones DS, Zhou J, Xu B. Ultrashort cationic naphthalene-derived self-assembled peptides as antimicrobial nanomaterials.

Biomacromolecules 2014;15:3429-3439.

[9] Flynn PB, Busetti A, Wielogorska E, Chevallier OP, Elliott CT, Laverty G, Gorman SP, Graham WG, Gilmore BF. Non-thermal plasma exposure rapidly attenuates bacterial AHLdependent quorum sensing and virulence. Sci Rep 2016;6:26320.

[10] Mu H, Tang J, Liu Q, Sun C, Wang T, Duan J. Potent Antibacterial nanoparticles against biofilm and intracellular bacteria. Sci Rep 2016;6:18877. 
[11] McCloskey AP, Gilmore BF, Laverty G. Evolution of antimicrobial peptides to selfassembled peptides for biomaterial applications. Pathogens 2014;3:791-821.

[12] Tong SY, Davis JS, Eichenberger E, Holland TL, Fowler VG,Jr. Staphylococcus aureus infections: epidemiology, pathophysiology, clinical manifestations, and management. Clin Microbiol Rev 2015;28:603-661.

[13] Gazit E. Self-assembled peptide nanostructures: the design of molecular building blocks and their technological utilization. Chem Soc Rev 2007;36:1263-1269.

[14] Gratton SE, Ropp PA, Pohlhaus PD, Luft JC, Madden VJ, Napier ME, DeSimone JM. The effect of particle design on cellular internalization pathways. Proc Natl Acad Sci U S A 2008;105:11613-11618.

[15] Barua S, Yoo JW, Kolhar P, Wakankar A, Gokarn YR, Mitragotri S. Particle shape enhances specificity of antibody-displaying nanoparticles. Proc Natl Acad Sci U S A 2013;110:3270-3275

[16] Kolhar P, Anselmo AC, Gupta V, Pant K, Prabhakarpandian B, Ruoslahti E, Mitragotri S. Using shape effects to target antibody-coated nanoparticles to lung and brain endothelium. Proc Natl Acad Sci U S A 2013;110:10753-10758.

[17] Zhang Y, Chan HF, Leong KW. Advanced materials and processing for drug delivery: the past and the future. Adv Drug Deliv Rev 2013;65:104-120.

[18] Rafferty J, Nagaraj H, McCloskey AP, Huwaitat R, Porter S, Albadr A, Laverty G.

Peptide Therapeutics and the pharmaceutical industry: barriers encountered translating from the laboratory to patients. Curr Med Chem 2016;23:4231-4259.

[19] Jeon J, Mills CE, Shell MS. Molecular insights into diphenylalanine nanotube assembly: all-atom simulations of oligomerization. J Phys Chem B 2013;117:3935-3943.

[20] Yan X, He Q, Wang K, Duan L, Cui Y, Li J. Transition of cationic dipeptide nanotubes into vesicles and oligonucleotide delivery. Angew Chem Int Ed Engl 2007;46:2431-2434. 
[21] Schnaider L, Brahmachari S, Schmidt NW, Mensa B, Shaham-Niv S, Bychenko D, Adler-Abramovich L, Shimon LJW, Kolusheva S, DeGrado WF, Gazit E. Self-assembling dipeptide antibacterial nanostructures with membrane disrupting activity. Nat Commun 2017;8:1365-017-01447-x.

[22] Laverty G, McLaughlin M, Shaw C, Gorman SP, Gilmore BF. Antimicrobial activity of short, synthetic cationic lipopeptides. Chem Biol Drug Des 2010;75:563-569.

[23] McCloskey AP, Gilmore SM, Zhou J, Draper ER, Porter S, Gilmore BF, Xu B, Laverty G. Self-assembling ultrashort NSAID-peptide nanosponges: multifunctional antimicrobial and anti-inflammatory materials. RSC Adv 2016;6:114738-114749.

[24] Alkawareek MY, Algwari QT, Gorman SP, Graham WG, O'Connell D, Gilmore BF. Application of atmospheric pressure nonthermal plasma for the in vitro eradication of bacterial biofilms. FEMS Immunol Med Microbiol 2012;65:381-384.

[25] Alshraiedeh NH, Alkawareek MY, Gorman SP, Graham WG, Gilmore BF. Atmospheric pressure, nonthermal plasma inactivation of MS2 bacteriophage: effect of oxygen concentration on virucidal activity. J Appl Microbiol 2013;115:1420-1426.

[26] Lv Y, Wang J, Gao H, Wang Z, Dong N, Ma Q, Shan A. Antimicrobial properties and membrane-active mechanism of a potential alpha-helical antimicrobial derived from cathelicidin PMAP-36. PLoS One 2014;9:e86364.

[27] Ceri H, Olson ME, Stremick C, Read RR, Morck D, Buret A. The Calgary Biofilm Device: new technology for rapid determination of antibiotic susceptibilities of bacterial biofilms. J Clin Microbiol 1999;37:1771-1776.

[28] Adler-Abramovich L, Gazit E. The physical properties of supramolecular peptide assemblies: from building block association to technological applications. Chem Soc Rev 2014;43:6881-6893. 
[29] Massey AS, Pentlavalli S, Cunningham R, McCrudden CM, McErlean EM, Redpath P, Ali AA, Annett S, McBride JW, McCaffrey J, Robson T, Migaud ME, McCarthy HO. Potentiating the anticancer properties of bisphosphonates by nanocomplexation with the cationic amphipathic peptide, RALA. Mol Pharm 2016;13:1217-1228.

[30] Pankey GA, Sabath LD. Clinical relevance of bacteriostatic versus bactericidal mechanisms of action in the treatment of Gram-positive bacterial infections. Clin Infect Dis 2004;38:864-870.

[31] Zgurskaya HI, Lopez CA, Gnanakaran S. Permeability barrier of Gram-negative cell envelopes and approaches to bypass it. ACS Infect Dis 2015;1:512-522.

[32] Huwaitat R, McCloskey AP, Gilmore BF, Laverty G. Potential strategies for the eradication of multidrug-resistant Gram-negative bacterial infections. Future Microbiol 2016;11:955-972.

[33] Sanchez CJ,Jr, Akers KS, Romano DR, Woodbury RL, Hardy SK, Murray CK, Wenke JC. D-amino acids enhance the activity of antimicrobials against biofilms of clinical wound isolates of Staphylococcus aureus and Pseudomonas aeruginosa. Antimicrob Agents Chemother 2014;58:4353-4361.

[34] Manabe T, Kawasaki K. D-form KLKLLLLLKLK-NH 2 peptide exerts higher antimicrobial properties than its L-form counterpart via an association with bacterial cell wall components. Sci Rep 2017;7:43384.

[35] Falciani C, Lozzi L, Pollini S, Luca V, Carnicelli V, Brunetti J, Lelli B, Bindi S, Scali S, Di Giulio A, Rossolini GM, Mangoni ML, Bracci L, Pini A. Isomerization of an antimicrobial peptide broadens antimicrobial spectrum to Gram-positive bacterial pathogens. PLoS One 2012;7:e46259.

[36] Grassi L, Maisetta G, Esin S, Batoni G. Combination strategies to enhance the efficacy of antimicrobial peptides against bacterial biofilms. Front Microbiol 2017;8:2409. 
[37] Laverty G, Gorman SP, Gilmore BF. The potential of antimicrobial peptides as biocides. Int J Mol Sci 2011;12:6566-6596.

[38] Fernandez-Lopez S, Kim HS, Choi EC, Delgado M, Granja JR, Khasanov A,

Kraehenbuehl K, Long G, Weinberger DA, Wilcoxen KM, Ghadiri MR. Antibacterial agents based on the cyclic D,L-alpha-peptide architecture. Nature 2001;412:452-455.

[39] Hashemi MM, Rovig J, Weber S, Hilton B, Forouzan MM, Savage PB. Susceptibility of colistin-resistant, Gram-negative bacteria to antimicrobial peptides and ceragenins. Antimicrob Agents Chemother 2017;61:10.1128/AAC.00292-17. Print 2017 Aug.

[40] Limoli DH, Jones CJ, Wozniak DJ. Bacterial extracellular polysaccharides in biofilm formation and function. Microbiol Spectr 2015;3:10.1128/microbiolspec.MB-0011-2014.

[41] Zasloff M. Antimicrobial peptides of multicellular organisms. Nature 2002;415:389-395.

[42] Epand RM, Epand RF. Lipid domains in bacterial membranes and the action of antimicrobial agents. Biochim Biophys Acta 2009;1788:289-294.

[43] Matsuzaki K. Control of cell selectivity of antimicrobial peptides. Biochim Biophys Acta 2009;1788:1687-1692.

[44] Ebenhan T, Gheysens O, Kruger HG, Zeevaart JR, Sathekge MM. Antimicrobial peptides: their role as infection-selective tracers for molecular imaging. Biomed Res Int 2014;2014:867381.

[45] McHenry AJ, Sciacca MF, Brender JR, Ramamoorthy A. Does cholesterol suppress the antimicrobial peptide induced disruption of lipid raft containing membranes? Biochim Biophys Acta 2012;1818:3019-3024.

[46] Strom MB, Haug BE, Skar ML, Stensen W, Stiberg T, Svendsen JS. The pharmacophore of short cationic antibacterial peptides. J Med Chem 2003;46:1567-1570. 
[47] Tang C, Smith AM, Collins RF, Ulijn RV, Saiani A. Fmoc-diphenylalanine self-assembly mechanism induces apparent pKa shifts. Langmuir 2009;25:9447-9453.

[48] Tian X, Sun F, Zhou XR, Luo SZ, Chen L. Role of peptide self-assembly in antimicrobial peptides. J Pept Sci 2015;21:530-539.

[49] Takeda S, Sato N, Rakugi H, Morishita R. Molecular mechanisms linking diabetes mellitus and Alzheimer disease: beta-amyloid peptide, insulin signaling, and neuronal function. Mol Biosyst 2011;7:1822-1827.

[50] Soscia SJ, Kirby JE, Washicosky KJ, Tucker SM, Ingelsson M, Hyman B, Burton MA,

Goldstein LE, Duong S, Tanzi RE, Moir RD. The Alzheimer's disease-associated amyloid beta-protein is an antimicrobial peptide. PLoS One 2010;5:e9505.

[51] Last NB, Miranker AD. Common mechanism unites membrane poration by amyloid and antimicrobial peptides. Proc Natl Acad Sci U S A 2013;110:6382-6387.

[52] Kagan BL, Jang H, Capone R, Teran Arce F, Ramachandran S, Lal R, Nussinov R. Antimicrobial properties of amyloid peptides. Mol Pharm 2012;9:708-717. 